\title{
The synthesis of tripolyphosphate using a one-stage method and a laboratory rotary kiln
}

\author{
Zygmunt Kowalski, Agnieszka Makara \\ Cracow University of Technology, Institute of Chemistry and Inorganic Technology, Warszawska 24, 31-155 Cracow, Poland \\ "Corresponding author: e-mail: zkow@chemia.pk.edu.pl
}

\begin{abstract}
In the study, sodium tripolyphosphate (STPP) was obtained according to the one-stage method. Batch mixes with varied degrees of soda ash neutralization were produced using thermal or wet processing phosphoric acid and/ or recycled STPP calcined in a laboratory rotary kiln. Chromatographic analysis of the phosphate forms showed that products containing as much as $94.73 \%$ of a single component were produced. At STPP recycling rates of 2.5 and 5, products with a low bulk density ranging between $0.437-0.547 \mathrm{~kg} / \mathrm{dm}^{3}$ were obtained. The recycling of STPP reduces the insoluble substance content, which affects the properties of the product. The phase composition of the products largely depends on the type of recycled phase of sodium tripolyphosphate (phase I and/or phase II) and the calcining temperature.
\end{abstract}

Keywords: sodium tripolyphosphate, rotary kiln, calcining, one-stage method.

\section{INTRODUCTION}

Sodium tripolyphosphate $\left(\mathrm{Na}_{5} \mathrm{P}_{3} \mathrm{O}_{10} ; \mathrm{STPP}\right)$ is a crystalline inorganic salt that can exist in two anhydrous crystalline forms (phase I and phase II) or a hydrous form $\left(\mathrm{Na}_{5} \mathrm{P}_{3} \mathrm{O}_{10} \cdot 6 \mathrm{H}_{2} \mathrm{O}\right)^{1-4}$. One method for the production of STPP is one-stage dehydration. The drying and calcining of the sodium orthophosphate mixture, which is obtained via phosphoric acid neutralization with sodium carbonate or hydroxide, occurs in a single technological operation within rotary kilns, fluid beds or spraying towers ${ }^{5,6}$. In the proposed method, concentrated phosphoric acid and solid $\mathrm{Na}_{2} \mathrm{CO}_{3}$ (dosed in the appropriate volume to obtain a $\mathrm{Na}_{2} \mathrm{O} / \mathrm{P}_{2} \mathrm{O}_{5}$ mole ratio of $1.67 \mathrm{TM}$ ) are mixed with the recycled final product (STPP), while the resulting semi-dry mixture is dosed to the rotary kiln. The appropriate proportion of solid and liquid phases causes the resulting mixture to have the consistency of moist fine sand without caking, and the material can be easily transported with classic mechanical conveyors for calcining in rotary furnaces. Depending on the parameters, the product contains mainly STPP in the low-temperature form of phase II, the high-temperature form of phase I, or a mixture of both, as well as small amounts of metaphosphate or tetrasodium diphosphate ${ }^{6-8}$.

This work presents results of research on STPP production with one stage method and using recycling of produced STPP calcined in laboratory rotary kiln. The goal of research was determination of applicable composition of raw materials charge allowed obtaining of STPP with the best quality.

\section{EXPERIMENTAL}

\begin{abstract}
Apparatus
Calcining was performed in a laboratory rotary kiln, to which the batch mixture was dosed using a Fritsch Laborette 24 vibration feeder. The phase composition of the products was identified ex situ tests using a Philips X-Pert diffractometer equipped with a PW W 1752/00 graphite monochromator, and $\mathrm{Cu} \mathrm{K} \alpha$ radiation and a $\mathrm{Ni}$ filter were applied. The determination of the amount of various phosphate forms in the resulting products was performed using ionic liquid chromatography using a chromatographic kit produced by DIONEX. The determination of the amount of phosphates converted to $\mathrm{P}_{2} \mathrm{O}_{5}$ was performed according to a spectrophotometric method using a Marcel Media spectrophotometer. For the bulk density analysis, sieve kits with mesh dimensions [mm] of 1.00, 0.85, 0.60 and 0.25 were used to obtain granulation fractions with the appropriate dimensions. Moreover, a metal measurement cylinder with a capacity of $25 \mathrm{~cm}^{3}$ was used to directly measure the bulk density.
\end{abstract}

\section{Methodology}

The present study involved wet process phosphoric acid (WAPP, Alwernia) obtained from Alwernia Chemical Company, chemically pure thermal phosphoric acid (purchased from POCH S.A.) and STPP, the final product. The neutralization of phosphoric acid was performed using soda ash (class I) obtained from Alwernia Chemical Company. The chemical composition of WAPP Alwernia and STPP applied for recycling has been provided in previous reports, ${ }^{6,10}$. The chemical compositions of phosphoric acids are shown in Table 1.

Table 1. The chemical composition of phosphoric acids

\begin{tabular}{|c|c|c|c|c|c|c|c|c|c|c|c|c|c|c|c|c|c|c|}
\hline $\begin{array}{l}\text { Phosphoric } \\
\text { acid }\end{array}$ & \multicolumn{18}{|c|}{ Content of components } \\
\hline \multirow{3}{*}{$\begin{array}{l}\text { WAPP Alwernia } \\
72.72 \%\end{array}$} & $\mathrm{Al}$ & As & B & $\mathrm{Cd}$ & Co & $\mathrm{Cr}$ & $\mathrm{Cu}$ & $\mathrm{Fe}$ & $\mathrm{Hg}$ & $\mathrm{Mn}$ & $\mathrm{Ni}$ & $\mathrm{Pb}$ & $\mathrm{Ti}$ & $\mathrm{V}$ & $\mathrm{Zn}$ & $\mathrm{Ca}$ & $\mathrm{SO}_{4}$ & $\mathrm{~F}$ \\
\hline & \multicolumn{16}{|c|}{$[\mathrm{mg} / \mathrm{kg}]$} & \multicolumn{2}{|c|}{$[\% \mathrm{~m} / \mathrm{m}]$} \\
\hline & 300 & $<0.05$ & 7.8 & 1.0 & 0.70 & 25 & 0.072 & 762 & $<0.05$ & 69 & 5.6 & 0.25 & 18 & 17 & 44 & 192 & 0.25 & 0.092 \\
\hline \multirow{3}{*}{$\begin{array}{l}\text { Thermal } \\
63.66 \%\end{array}$} & \multicolumn{5}{|c|}{ Reducing substances } & \multicolumn{4}{|c|}{$\mathrm{NO}_{3}^{-}$} & \multicolumn{5}{|c|}{$\mathrm{Cl}^{-}$} & \multicolumn{4}{|c|}{$\mathrm{SO}_{4}{ }^{2-}$} \\
\hline & \multicolumn{18}{|c|}{$[\% \mathrm{~m} / \mathrm{m}]$} \\
\hline & \multicolumn{5}{|c|}{$\max .0 .005$} & \multicolumn{4}{|c|}{$\max .0 .0006$} & \multicolumn{5}{|c|}{$\max .0 .0005$} & \multicolumn{4}{|c|}{$\max .0 .003$} \\
\hline
\end{tabular}


Batch mixtures with the appropriate composition were prepared by mixing reagents, grinding with a mortar and calcining. Calcining was performed on mixtures with recirculated STPP while maintaining $\mathrm{TM}=1.67$, without recirculating the final product and mixture. Solutions of concentrated phosphoric acid were dosed with soda ash (in the appropriate volume to preserve the TM), and the mixture was ground with a mortar until a semi-dry state was achieved. In the present study, variable, stoichiometric neutralization was applied via the reaction of sodium tripolyphosphate $(\mathrm{TM}=1.67)$. Decreased and increased neutralization levels TM (amounting to 1.57 and 1.77 , respectively) were also evaluated. While grinding the prepared mixture, sodium tripolyphosphate was dosed in portions in the form of phase I, phase II or a mixture of both phases in a quantity corresponding to a weight ratio STPP/batch $=2.5 / 1$ and 5/1. At the end of STPP dosing, the mixture was ground until uniform material was obtained. STPP recycling in the form of phase I and phase II (separately) and a mixture of both phases (phase II and phase I) was applied to mixtures produced with a TM of 1.67 at a recycling rate of 2.5/1. In mixtures obtained at $\mathrm{TM}=1.57$, STPP recycling was only applied in the form of phase II (at a recycling rate of 5/1). In mixtures where the $\mathrm{TM}$ was set to 1.77 , a five-fold STPP recycling rate was applied, and phase I was used exclusively.
Mixtures were dosed into the back current of the laboratory rotary kiln, which was heated with an electric heater to the appropriate temperature prior to dosing. Furnace rotations were selected in such a way so that the mixture remained inside the furnace for exactly one hour. Calcining of all of the mixtures was performed at a temperature of either $350^{\circ} \mathrm{C}$ or $450^{\circ} \mathrm{C}$.

The phase composition of the products was determined according to the structural X-ray method, and the content of various phosphate forms was determined using ionic liquid chromatography (converted into $\mathrm{Na}_{2} \mathrm{HPO}_{4}, \mathrm{Na}_{4} \mathrm{P}_{2} \mathrm{O}_{7}, \mathrm{Na}_{5} \mathrm{P}_{3} \mathrm{O}_{10}$, and $\left.\mathrm{Na}_{6}\left(\mathrm{PO}_{3}\right)_{6}\right)$. Each sample was dissolved in water and then filtrated, and a filtrate containing water soluble phosphates was analysed $^{6}$. The determination of the content of substances insoluble in water was performed according to the weight method $^{11}$. On the basis of densitometric analysis, bulk density measurements were performed on dry products with strictly determined granulations ${ }^{12}$. The amount of phosphate converted into $\mathrm{P}_{2} \mathrm{O}_{5}$ was determined according to a spectrophotometric method ${ }^{13}$.

\section{RESULTS}

Research concerning of STPP production methods were presented in many paper describing process parameter of worked out one stage and two stage STPP technologies. The goal of research on two stage technology was determination of proper process parameters allowed ob-

Table 2. Phase composition of products obtained from the calcining of thermal phosphoric acid (T) and WAPP Alwernia (A) with soda ash and/or recycled STPP for 60 minutes

\begin{tabular}{|c|c|c|c|c|c|c|c|}
\hline \multirow{2}{*}{$\mathrm{TM}$} & \multirow{2}{*}{$\begin{array}{c}\text { Recycling } \\
\text { (product/batch) }\end{array}$} & \multirow{2}{*}{ Recycled STPP phase } & \multirow{2}{*}{$\begin{array}{l}\text { Temp. } \\
{\left[{ }^{\circ} \mathrm{C}\right]}\end{array}$} & \multicolumn{2}{|r|}{ Thermal acid } & \multicolumn{2}{|r|}{ WAPP Alwernia } \\
\hline & & & & No. & Phase composition & No. & Phase composition \\
\hline 1.67 & 0 & 0 & \multirow{6}{*}{350} & $1 \mathrm{~T}$ & $\begin{array}{c}\mathrm{Na}_{4} \mathrm{P}_{2} \mathrm{O}_{7} \\
\mathrm{Na}_{5} \mathrm{P}_{3} \mathrm{O}_{10}(\mathrm{II}) \\
\mathrm{Na}_{3} \mathrm{P}_{3} \mathrm{O}_{9}\end{array}$ & $1 \mathrm{~A}$ & $\begin{array}{c}\mathrm{Na}_{4} \mathrm{P}_{2} \mathrm{O}_{7} \\
\mathrm{Na}_{5} \mathrm{P}_{3} \mathrm{O}_{10}(\mathrm{II}) \\
\mathrm{Na}_{5} \mathrm{P}_{3} \mathrm{O}_{10}(\mathrm{I}) \\
\mathrm{Na}_{3} \mathrm{P}_{3} \mathrm{O}_{9}\end{array}$ \\
\hline 1.67 & $2.5 / 1$ & $F \|$ & & $2 \mathrm{~T}$ & $\begin{array}{c}\mathrm{Na}_{4} \mathrm{P}_{2} \mathrm{O}_{7} \\
\mathrm{Na}_{5} \mathrm{P}_{3} \mathrm{O}_{10}(\mathrm{II}) \\
\end{array}$ & $2 \mathrm{~A}$ & $\begin{array}{c}\mathrm{Na}_{4} \mathrm{P}_{2} \mathrm{O}_{7} \\
\mathrm{Na}_{5} \mathrm{P}_{3} \mathrm{O}_{10}(\mathrm{II}) \\
\end{array}$ \\
\hline 1.67 & $2.5 / 1$ & $\mathrm{~F} I+\mathrm{F} \|$ & & $3 \mathrm{~T}$ & $\begin{array}{c}\mathrm{Na}_{4} \mathrm{P}_{2} \mathrm{O}_{7} \\
\mathrm{Na}_{5} \mathrm{P}_{3} \mathrm{O}_{10}(\mathrm{II}) \\
\mathrm{Na}_{5} \mathrm{P}_{3} \mathrm{O}_{10}(\mathrm{I}) \\
\mathrm{Na}_{5} \mathrm{P}_{3} \mathrm{O}_{10} \cdot 6 \mathrm{H}_{2} \mathrm{O}\end{array}$ & $3 \mathrm{~A}$ & $\begin{array}{c}\mathrm{Na}_{4} \mathrm{P}_{2} \mathrm{O}_{7} \\
\mathrm{Na}_{5} \mathrm{P}_{3} \mathrm{O}_{10}(\mathrm{II}) \\
\mathrm{Na}_{5} \mathrm{P}_{3} \mathrm{O}_{10}(\mathrm{I}) \\
\mathrm{Na}_{5} \mathrm{P}_{3} \mathrm{O}_{10} \cdot 6 \mathrm{H}_{2} \mathrm{O}\end{array}$ \\
\hline 1.67 & $2.5 / 1$ & F I & & $4 \mathrm{~T}$ & $\begin{array}{c}\mathrm{Na}_{4} \mathrm{P}_{2} \mathrm{O}_{7} \\
\mathrm{Na}_{5} \mathrm{P}_{3} \mathrm{O}_{10}(\mathrm{II}) \\
\mathrm{Na}_{5} \mathrm{P}_{3} \mathrm{O}_{10}(\mathrm{I}) \\
\mathrm{Na}_{5} \mathrm{P}_{3} \mathrm{O}_{10} \cdot 6 \mathrm{H}_{2} \mathrm{O}\end{array}$ & $4 \mathrm{~A}$ & $\begin{array}{c}\mathrm{Na}_{4} \mathrm{P}_{2} \mathrm{O}_{7} \\
\mathrm{Na}_{5} \mathrm{P}_{3} \mathrm{O}_{10}(\mathrm{II}) \\
\mathrm{Na}_{5} \mathrm{P}_{3} \mathrm{O}_{10}(\mathrm{I}) \\
\mathrm{Na}_{5} \mathrm{P}_{3} \mathrm{O}_{10} \cdot 6 \mathrm{H}_{2} \mathrm{O}\end{array}$ \\
\hline 1.57 & $5 / 1$ & $F \|$ & & $5 \mathrm{~T}$ & $\begin{array}{c}\mathrm{Na}_{4} \mathrm{P}_{2} \mathrm{O}_{7} \\
\mathrm{Na}_{5} \mathrm{P}_{3} \mathrm{O}_{10}(\mathrm{II}) \\
\end{array}$ & $5 \mathrm{~A}$ & $\begin{array}{c}\mathrm{Na}_{4} \mathrm{P}_{2} \mathrm{O}_{7} \\
\mathrm{Na}_{5} \mathrm{P}_{3} \mathrm{O}_{10}(\mathrm{II}) \\
\end{array}$ \\
\hline 1.77 & $5 / 1$ & FI & & $6 \mathrm{~T}$ & $\begin{array}{c}\mathrm{Na}_{4} \mathrm{P}_{2} \mathrm{O}_{7} \\
\mathrm{Na}_{5} \mathrm{P}_{3} \mathrm{O}_{10}(\mathrm{II}) \\
\mathrm{Na}_{5} \mathrm{P}_{3} \mathrm{O}_{10}(\mathrm{I})\end{array}$ & $6 \mathrm{~A}$ & $\begin{array}{c}\mathrm{Na}_{4} \mathrm{P}_{2} \mathrm{O}_{7} \\
\mathrm{Na}_{5} \mathrm{P}_{3} \mathrm{O}_{10}(\mathrm{II}) \\
\mathrm{Na}_{5} \mathrm{P}_{3} \mathrm{O}_{10}(\mathrm{I}) \\
\mathrm{Na}_{5} \mathrm{P}_{3} \mathrm{O}_{10} \cdot 6 \mathrm{H}_{2} \mathrm{O}\end{array}$ \\
\hline 1.67 & 0 & 0 & \multirow{6}{*}{450} & $7 \mathrm{~T}$ & $\begin{array}{c}\mathrm{Na}_{4} \mathrm{P}_{2} \mathrm{O}_{7} \\
\mathrm{Na}_{5} \mathrm{P}_{3} \mathrm{O}_{10}(\mathrm{II}) \\
\mathrm{Na}_{5} \mathrm{P}_{3} \mathrm{O}_{10}(\mathrm{I}) \\
\end{array}$ & $7 \mathrm{~A}$ & $\begin{array}{c}\mathrm{Na}_{4} \mathrm{P}_{2} \mathrm{O}_{7} \\
\mathrm{Na}_{5} \mathrm{P}_{3} \mathrm{O}_{10}(\mathrm{II}) \\
\mathrm{Na}_{5} \mathrm{P}_{3} \mathrm{O}_{10}(\mathrm{I}) \\
\end{array}$ \\
\hline 1.67 & $2.5 / 1$ & F II & & $8 \mathrm{~T}$ & $\begin{array}{c}\mathrm{Na}_{4} \mathrm{P}_{2} \mathrm{O}_{7} \\
\mathrm{Na}_{5} \mathrm{P}_{3} \mathrm{O}_{10}(\mathrm{II}) \\
\mathrm{Na}_{5} \mathrm{P}_{3} \mathrm{O}_{10}(\mathrm{I}) \\
\end{array}$ & $8 \mathrm{~A}$ & $\begin{array}{c}\mathrm{Na}_{4} \mathrm{P}_{2} \mathrm{O}_{7} \\
\mathrm{Na}_{5} \mathrm{P}_{3} \mathrm{O}_{10}(\mathrm{II})\end{array}$ \\
\hline 1.67 & $2.5 / 1$ & $F I+F \|$ & & $9 \mathrm{~T}$ & $\begin{array}{c}\mathrm{Na}_{4} \mathrm{P}_{2} \mathrm{O}_{7} \\
\mathrm{Na}_{5} \mathrm{P}_{3} \mathrm{O}_{10}(\mathrm{II}) \\
\mathrm{Na}_{5} \mathrm{P}_{3} \mathrm{O}_{10}(\mathrm{I}) \\
\end{array}$ & $9 \mathrm{~A}$ & $\begin{array}{c}\mathrm{Na}_{4} \mathrm{P}_{2} \mathrm{O}_{7} \\
\mathrm{Na}_{5} \mathrm{P}_{3} \mathrm{O}_{10} \text { (II) } \\
\mathrm{Na}_{5} \mathrm{P}_{3} \mathrm{O}_{10}(\mathrm{I}) \\
\end{array}$ \\
\hline 1.67 & $2.5 / 1$ & FI & & 10T & $\begin{array}{c}\mathrm{Na}_{4} \mathrm{P}_{2} \mathrm{O}_{7} \\
\mathrm{Na}_{5} \mathrm{P}_{3} \mathrm{O}_{10}(\mathrm{II}) \\
\mathrm{Na}_{5} \mathrm{P}_{3} \mathrm{O}_{10}(\mathrm{I}) \\
\end{array}$ & $10 \mathrm{~A}$ & $\begin{array}{c}\mathrm{Na}_{4} \mathrm{P}_{2} \mathrm{O}_{7} \\
\mathrm{Na}_{5} \mathrm{P}_{3} \mathrm{O}_{10}(\mathrm{II}) \\
\mathrm{Na}_{5} \mathrm{P}_{3} \mathrm{O}_{10}(\mathrm{I})\end{array}$ \\
\hline 1.57 & $5 / 1$ & F II & & $11 \mathrm{~T}$ & $\mathrm{Na}_{5} \mathrm{P}_{3} \mathrm{O}_{10}(\mathrm{II})$ & $11 \mathrm{~A}$ & $\begin{array}{c}\mathrm{Na}_{4} \mathrm{P}_{2} \mathrm{O}_{7} \\
\mathrm{Na}_{5} \mathrm{P}_{3} \mathrm{O}_{10} \text { (II) } \\
\mathrm{Na}_{5} \mathrm{P}_{3} \mathrm{O}_{10}(\mathrm{I}) \\
\end{array}$ \\
\hline 1.77 & $5 / 1$ & F I & & $12 \mathrm{~T}$ & $\begin{array}{c}\mathrm{Na}_{4} \mathrm{P}_{2} \mathrm{O}_{7} \\
\mathrm{Na}_{5} \mathrm{P}_{3} \mathrm{O}_{10}(\mathrm{II}) \\
\mathrm{Na}_{5} \mathrm{P}_{3} \mathrm{O}_{10}(\mathrm{I}) \\
\end{array}$ & $12 \mathrm{~A}$ & $\begin{array}{c}\mathrm{Na}_{4} \mathrm{P}_{2} \mathrm{O}_{7} \\
\mathrm{Na}_{5} \mathrm{P}_{3} \mathrm{O}_{10}(\mathrm{II}) \\
\mathrm{Na}_{5} \mathrm{P}_{3} \mathrm{O}_{10}(\mathrm{I}) \\
\end{array}$ \\
\hline
\end{tabular}


Table 3. Phosphate forms and insoluble substances in the calcining products from thermal phosphoric acid (T) with soda ash and/ or recycled STPP

\begin{tabular}{|c|c|c|c|c|c|}
\hline \multirow{2}{*}{ No. } & \multicolumn{4}{|c|}{ Content of phosphate forms $[\% \mathrm{~m} / \mathrm{m}]$ converted into: } & \multirow{2}{*}{$\begin{array}{c}\text { Substances insoluble in } \\
\text { water }[\% \mathrm{~m} / \mathrm{m}]\end{array}$} \\
\hline & $\mathrm{Na}_{2} \mathrm{HPO}_{4}$ & $\mathrm{Na}_{4} \mathrm{P}_{2} \mathrm{O}_{7}$ & $\mathrm{Na}_{5} \mathrm{P}_{3} \mathrm{O}_{10}$ & $\mathrm{Na}_{6}\left(\mathrm{PO}_{3}\right)_{6}$ & \\
\hline 1T & 1.97 & 5.15 & 87.56 & 5.32 & 0.32 \\
\hline $2 \mathrm{~T}$ & 2.52 & 5.75 & 87.86 & 3.87 & 0.05 \\
\hline $4 \mathrm{~T}$ & 2.16 & 5.49 & 87.45 & 4.90 & 0.02 \\
\hline $5 \mathrm{~T}$ & 0.93 & 3.75 & 92.94 & 2.38 & 0.01 \\
\hline $6 \mathrm{~T}$ & 2.76 & 7.63 & 87.16 & 2.45 & 0.06 \\
\hline $7 \mathrm{~T}$ & 0.97 & 10.95 & 85.43 & 2.65 & 0.28 \\
\hline $8 T$ & 1.08 & 4.38 & 92.12 & 2.42 & 0.13 \\
\hline 9T & 1.95 & 6.85 & 88.29 & 2.91 & 0.06 \\
\hline 10T & 1.54 & 6.02 & 89.07 & 3.37 & 0.05 \\
\hline $11 \mathrm{~T}$ & 0.60 & 2.96 & 94.73 & 1.71 & 0.30 \\
\hline $12 \mathrm{~T}$ & 1.97 & 6.15 & 86.56 & 5.32 & 0.00 \\
\hline
\end{tabular}

Table 4. Phosphate forms and insoluble substances in products of WAPP Alwernia (A), soda ash and/or recycled STPP

\begin{tabular}{|c|c|c|c|c|c|}
\hline \multirow{2}{*}{ No. } & \multicolumn{4}{|c|}{ Content of phosphate forms $[\% \mathrm{~m} / \mathrm{m}]$ converted into: } & \multirow{2}{*}{$\begin{array}{c}\text { Substances insoluble in } \\
\text { water }[\% \mathrm{~m} / \mathrm{m}]\end{array}$} \\
\hline & $\mathrm{Na}_{2} \mathrm{HPO}_{4}$ & $\mathrm{Na}_{4} \mathrm{P}_{2} \mathrm{O}_{7}$ & $\mathrm{Na}_{5} \mathrm{P}_{3} \mathrm{O}_{10}$ & $\mathrm{Na}_{6}\left(\mathrm{PO}_{3}\right)_{6}$ & \\
\hline $1 \mathrm{~A}$ & 2.16 & 17.85 & 73.90 & 6.09 & 0.21 \\
\hline $2 \mathrm{~A}$ & 1.37 & 5.29 & 90.62 & 2.72 & 0.75 \\
\hline $3 \mathrm{~A}$ & 1.83 & 6.34 & 89.69 & 2.14 & 0.08 \\
\hline $4 \mathrm{~A}$ & 2.55 & 10.16 & 84.10 & 3.19 & 0.00 \\
\hline $5 \mathrm{~A}$ & 0.93 & 3.38 & 92.71 & 2.98 & 0.35 \\
\hline $6 \mathrm{~A}$ & 2.74 & 10.12 & 84.90 & 2.24 & 0.00 \\
\hline $7 \mathrm{~A}$ & 1.26 & 16.29 & 78.91 & 3.54 & 0.25 \\
\hline $8 \mathrm{~A}$ & 1.11 & 5.66 & 91.10 & 2.13 & 0.09 \\
\hline 9A & 1.29 & 5.54 & 90.58 & 2.59 & 0.41 \\
\hline $10 \mathrm{~A}$ & 1.43 & 8.16 & 86.75 & 3.66 & 0.01 \\
\hline $11 \mathrm{~A}$ & 0.76 & 4.15 & 92.93 & 2.16 & 0.34 \\
\hline $12 \mathrm{~A}$ & 1.22 & 7.26 & 89.82 & 1.70 & 0.00 \\
\hline
\end{tabular}

taining of STPP with higher bulk density used especially into detergents production ${ }^{\mathbf{1 4}}$. Research concerning one stage method of STPP production comprised selection of process parameters of calcining realized in the chamber kiln and determination of influence of different type raw materials on quality of the products obtained ${ }^{6}$.

The goal of our research realized with use of laboratory rotary kiln was determination of process parameters and proportions of used raw materials to obtain products having applicable quality factor. $\mathrm{In}^{15}$ were presented result of research on STPP production with use of rotary kiln and WAPP neutralized with soda ash to $\mathrm{TM}=1.67$ and recycled STPP contained only Phase II (recycling rate related to the mass of phosphoric acid used in neutralization process). Presented researches were realized in two variants. The first one concerning of impurities free system (charges obtained from thermal phosphoric acid) and the second one contained impurities coming from WAPP used. STPP recycling rate (calculated as proportion of recycled STPP and mass of charge produced from phosphoric acid and soda ash) was 2.5/1 and 5/1.

The composition of batch mixtures, the parameters of the calcining process and the phase composition of calcining products, which was identified using the structural X-ray method, are presented in Table 2. The content of phosphate forms determined using ionic liquid chromatography and the identification of insoluble substances via the weight method are presented in Tables 3 and 4, respectively. The results of phosphate determination, as converted to $\mathrm{P}_{2} \mathrm{O}_{5}$ and the bulk densities of the materials are shown in Figure 1 and 2, respectively ${ }^{6}$.

The phase composition of the products largely depended on the type of crystalline phase in recirculated STPP (Table 2). In calcined batch samples from thermal phosphoric acid produced at $350^{\circ} \mathrm{C}$, to which a 2.5 -fold
$(\mathrm{TM}$ of batch mix $=1.67)$ and 5 -fold $(\mathrm{TM}=1.57)$ recycling rate of phase II was applied. Phase II STPP was obtained by adding tetrasodium diphosphate. A similar situation occurred at a calcining temperature of $450^{\circ} \mathrm{C}$, at which point the recycled phase consisted of phase II STPP (TM of batch mix $=1.57$ ) and the product only contained phase II. Products obtained at $350^{\circ} \mathrm{C}$ with the 2.5-fold recycling rate of phase I or a mixture of both phases (TM of the mixture of WAPP Alwernia and thermal acid $=1.67)$ with the 5-fold recycling rate of phase I $(\mathrm{TM}$ of the batch mixture of WAPP Alwernia = 1.77) contained both STPP phases. These products contained also the hexahydrate of pentasodium triphosphate and tetrasodium diphosphate. In products obtained from WAPP Alwernia and/or recycled STPP (regardless of the TM of the batch mix and the type of recycled STPP phase) at $450^{\circ} \mathrm{C}$, the phase composition consisted of both STPP phases and tetrasodium diphosphate. Phase II STPP and tetrasodium diphosphate was only obtained in the batch produced at a 2.5 -fold recirculation rate of phase II STPP from a mixture of acid and soda ash mixed at a $\mathrm{Na} / \mathrm{P}$ mole ratio of 1.67 , and phase I STPP was not detected ${ }^{6}$.

STPP recycling substitutes the process of STPP crystals nucleation. Recycled STPP functioned as inoculation of STPP crystals.

When analyzing the calcining products of thermal phosphoric acid using ionic liquid chromatography, the highest STPP contents $(92.94 \%$ and $94.73 \%$, samples 5 T and $11 \mathrm{~T}$, respectively, Table 3 ) were observed in mixes calcined at $350^{\circ} \mathrm{C}$ and $450^{\circ} \mathrm{C}$ when $\mathrm{TM}=1.57$ was applied, as well as a 5-fold recycling level of phase II STPP. In both cases, the content of insoluble substances was very low; amounting to only $0.01 \%$ and $0.30 \%$, respectively, while sodium tripolyphosphate was present in the form 
of phase II. Higher contents of STPP in the form of a mixture of both phases $(92.12 \%)$ were obtained at a temperature of $450^{\circ} \mathrm{C}$ by applying a 2.5 -fold recycling rate of phase II to a mixture of acid and water $(\mathrm{TM}=1.67)$.

In calcined products of mixtures of WAPP Alwernia, the content of sodium tripolyphosphate ranged from $73.90 \%$ to $92.93 \%$ (Table 4). The lowest content of $\mathrm{Na}_{5} \mathrm{P}_{3} \mathrm{O}_{10}$ was observed in the product obtained at a temperature of $350^{\circ} \mathrm{C}$ without STPP recycling. In addition, the highest content of pyrophosphate was observed in this product, as well as higher metaphosphate forms. Similar to products obtained by calcining batches of thermal acid, samples obtained at a TM of 1.57 and a 5-fold recycling rate of phase II STPP presented the highest content of $\mathrm{Na}_{5} \mathrm{P}_{3} \mathrm{O}_{10}$ and the lowest content of orthophosphate ${ }^{6}$.
In products obtained from thermal and wet process phosphoric acid Alwernia, the content of $\mathrm{P}_{2} \mathrm{O}_{5}$ ranged from $55 \%$ to $58 \%$ (Fig. 1). The observed differences are related to the TM values of reagents used for the preparation of batch mixes and the STPP recycling level. Higher contents of $\mathrm{P}_{2} \mathrm{O}_{5}$ were recorded for products obtained without recycled STPP. For samples obtained via tripolyphosphate recycling, the type of phosphoric acid did not affect the $\mathrm{P}_{2} \mathrm{O}_{5}$ content.

The bulk density of products obtained through the calcining of phosphoric acid and soda ash was significantly different from that of products obtained using recycled STPP (Fig. 2). Products with higher bulk densities $\left(\sim 0.7 \mathrm{~kg} / \mathrm{dm}^{3}\right)$ were obtained using thermal phosphoric acid and soda ash, while products with lower bulk densities $\left(0.4-0.5 \mathrm{~kg} / \mathrm{dm}^{3}\right)$ were obtained using

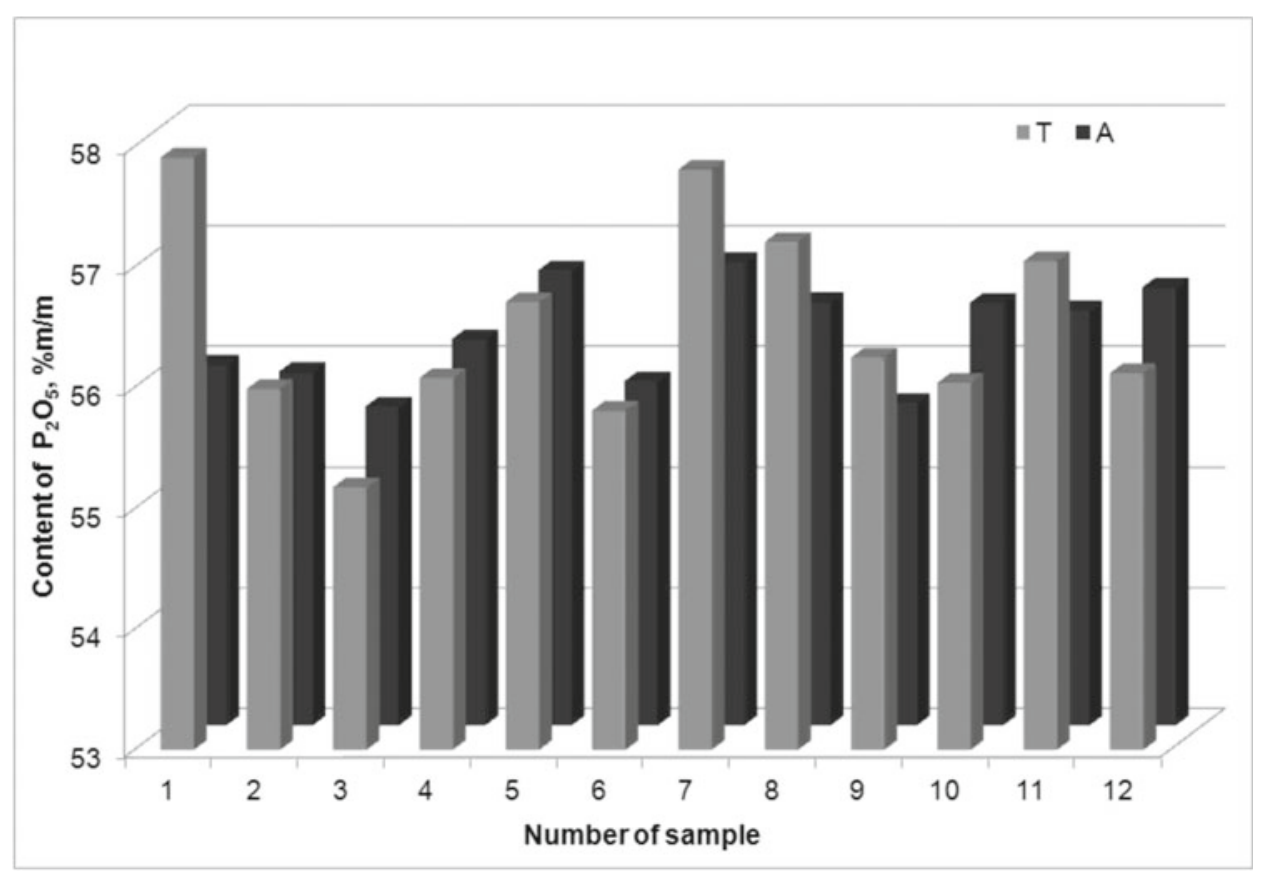

Figure 1. $\mathrm{P}_{2} \mathrm{O}_{5}$ content in the products from batches of thermal $(\mathrm{T})$ phosphoric acid and WAPP Alwernia (A) calcined in a rotary kiln

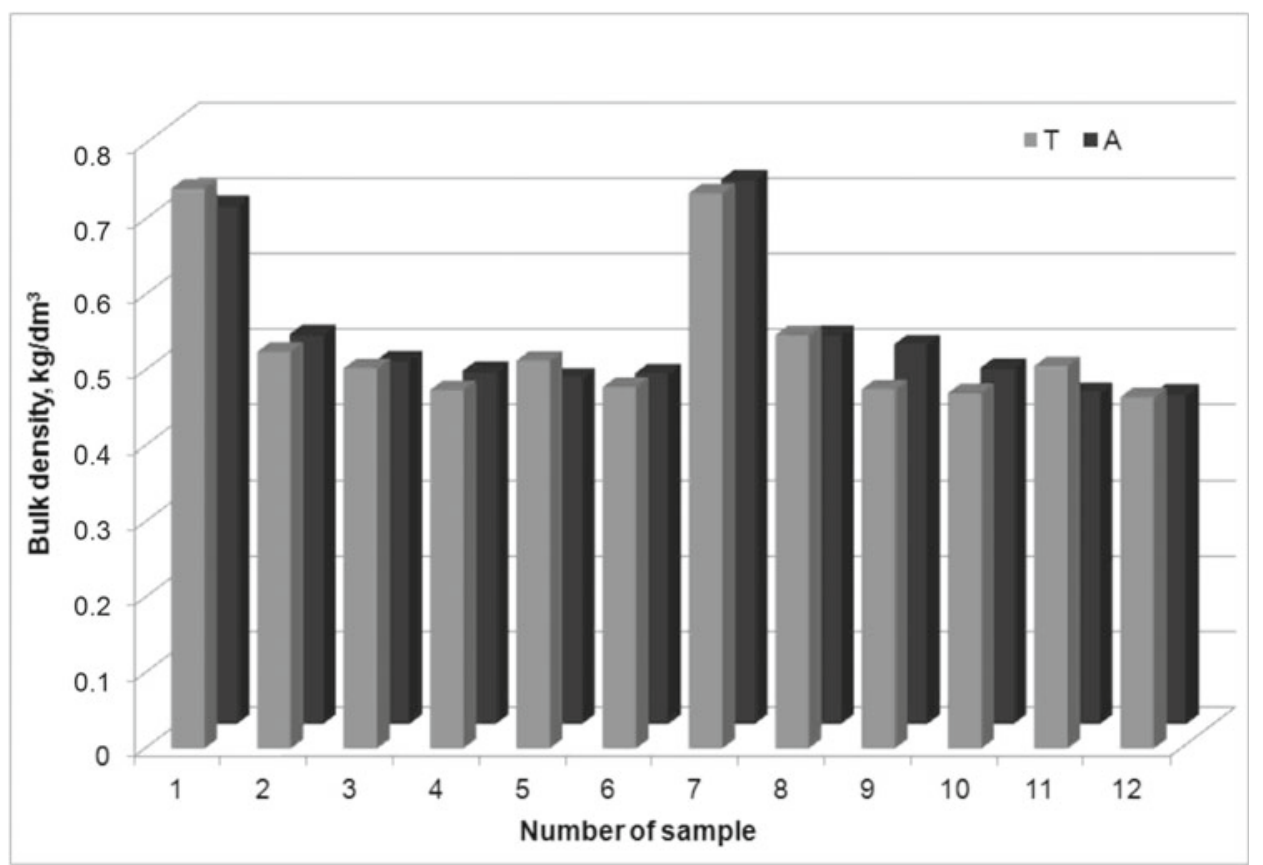

Figure 2. Bulk density of products from batches of thermal (T) phosphoric acid and WAPP Alwernia (A) calcined in a rotary kiln 
recycled STPP. Produced STPP with low bulk density is used in cosmetic and food industry. STPP with high bulk density produced with two stage method only is used for detergent production.

Products obtained by adding STPP to a batch of thermal phosphoric acid and soda ash presented higher bulk densities than products obtained from WAPP Alwernia. Products obtained as a result of calcining thermal phosphoric acid at $350^{\circ} \mathrm{C}$ or $450^{\circ} \mathrm{C}$ at a $\mathrm{TM}$ of 1.67 or 1.57 and a phase II recycling rate of $2.5 / 1$ and $5 / 1$ have greater bulk densities than products obtained at a TM of 1.77 when a five-fold STPP recycling rate was applied. In products with WAPP Alwernia, the greater values of bulk densities $\left(\sim 0.5 \mathrm{~kg} / \mathrm{dm}^{3}\right)$ were recorded for products obtained at $350^{\circ} \mathrm{C}$ and $450^{\circ} \mathrm{C}$, a TM of 1.67 , and a 2.5 -fold recycling rate of phase II. The results showed that the calcining temperature did not significantly affect the bulk density of the products. Calcining of mixtures of phosphoric acids with soda ash at temperatures of $350^{\circ} \mathrm{C}$ and $450^{\circ} \mathrm{C}$ and a $\mathrm{TM}$ of 1.67 without STPP recycling leads to a product with an average bulk density $\left(\sim 0.7 \mathrm{~kg} / \mathrm{dm}^{3}\right)^{6}$.

\section{CONCLUSIONS}

The results of the present study showed that when applying product recycling, semi-dry batch mixes that can be used in the calcining process in a rotary kiln are successfully obtained. By selecting the appropriate calcining process parameters and the proportions of solid and liquid phase, one can obtain a product containing more than $90 \%$ sodium tripolyphosphate. STPP recycling, in the case of products obtained from both thermal phosphoric acid and wet processed phosphoric acid, reduces the insoluble substance content. Regardless of the type of phosphoric acid used, the recycling of sodium tripolyphosphate, produces material with a low bulk density $\left(0.4-0.5 \mathrm{~kg} / \mathrm{dm}^{3}\right)$, and whereas products obtained exclusively from phosphoric acid and soda ash possesses a higher bulk density $\left(\sim 0.7 \mathrm{~kg} / \mathrm{dm}^{3}\right)$.

\section{ACKNOWLEDGEMENTS}

The present study was performed within research project No. 0888/B/H03/2011/40 of the Ministry of Science and Higher Education.

\section{LITERATURE CITED}

1. Van Wazer, J.R. (1958). Phosphorus and Its Compounds (Vol. 1). New York: Interscience Publishers.

2. Toy, A.D.E. (1973). The Chemistry of Phosphorus (Vol. 3). New York: Stauffer Chemical Company.

3. Davies, D.R. \& Corbridge, D.E.C. (1958). The Crystal Structure of Sodium Triphosphate, $\mathrm{Na}_{5} \mathrm{P}_{3} \mathrm{O}_{10}$, Phase II. Acta Crystallogr. 11, 315-319. DOI: 10.1107/S0365110X58000876.

4. Dymon, J.J. \& King, A.J. (1951). Structure studies of the two forms of sodium tripolyphosphate. Acta Crystallogr. 4, 378-379. DOI: 10.1107/S0365110X51001197.

5. Kowalski, Z., Kijkowska, R., Pawłowska-Kozińska, D. \& Wzorek, Z. (2002). Sodium tripolyphosphate and others condensed sodium phosphates production methods. Pol. J. Chem. Technol. 4, (3), 27-33.

6. Makara, A. (2012). Studies on production of sodium tripolyphosphate with a one-stage method with control of main ingredient content and crystalline phases. Ph.D. thesis, Cracow University of Technology, Cracow.

7. Makara, A., Kowalski, Z. \& Banach, M. (2011). Polish patent application P. 397098.

8. Makara, A., Kowalski, Z. \& Banach, M. (2011). Polish patent application P. 397286.

9. Makara, A., Kowalski, Z. \& Banach, M. (2011). Effect of chemical composition of phosphoric acid on the formation of sodium tripolyphosphate. Przem. Chem. 90/5, 900-903.

10. Makara, A., Kowalski, Z. \& Banach, M. (2012). Control of phase composition sodium tripolyphosphate at varying parameters of calcining and product recycling. Przem. Chem. 91/5, 860-864.

11. Polish standard PN-93 C-84300/21. Methods of testing of phosphorus salts. Determination of the content of insoluble substances in water.

12. Polish standard PN-80/C-04532. Determination of bulk density.

13. Polish standard PN 93/C-84300/03. Methods of testing of phosphorus salts. Determination of the total content of phosphorus(V) oxide.

14. Gorazda, K., Banach, M., Makara, A. \& Wzorek, Z. (2011). Increasing the bulk density of STPP - influence of the process parameters. Pol. J. Chem. Technol. 13, 2, 40-44.

15. Kijkowska, R., Kowalski, Z., Pawłowska-Kozińska, D., Wzorek, Z. \& Gorazda, K. (2008). Tripolyphosphate Made from Wet-Process Phosphoric Acid with the Use of a Rotary Kiln. Ind. Eng. Chem. Res. 47, 18, 6821-6827. DOI: 10.1021/ ie800412q. 